Kovács Nóra ${ }^{1}$ - Kékes Szabó Marietta ${ }^{2}$

${ }^{1}$ Szegedi Tudományegyetem JGYPK

${ }^{2}$ Szegedi Tudományegyetem JGYPK

\title{
Családkép és családideál napjainkban, avagy kisiskolások és pubertáskorú fiatalok vélekedései a családról
}

A családrendszer az egyén fejlódésének legfontosabb közege, melyben annak tagjai egymásra hatást gyakorolnak, kölcsönösen befolyásolva a másik érzésvilágát, gondolkodását és viselkedését. A család fontos alkotója a gyermek, akinek egészséges fejlódéséhez nem nélkü̈lözhetó a fenntartó rendszer rugalmas átalakulásra való képessége. Ezen szempontból pedig talán a serdülókor jelenti azt a szakaszt, ami a

legnagyobb kihívást állítja a család elé. A fiatal ugyanis ezen

idóperiódusban különösen érzékeny, identitása alakulóban van, szülei nézeteivel számos alkalommal ütközve keresi önnön hangját,

feszegeti határait, és mindinkább autonómiára törekszik.

Kutatásunkban a felnövekvó gyermekek családról alkotott észlelt (valós) és ideális (vágyott) képét kívántuk feltárni, összehasonlítani.

Ennek tükrében ugyanis az érintett korosztályoknál felmerüló életvezetési nehézségek, problémák átvilágithatóbbá válnak, ami a

fiatalokkal folytatott oktató-neveló munka hatékonyságára is

jótékony hatással birhat. Vizsgálatunkba 49 kisiskolás-és 48

serdülókorú fiatal került bevonásra. Eszközként Mányai (1990) családképet vizsgáló kérdôivét használtuk fel, ami a családi hatalom, - kohézió és -adaptivitás faktorok mentén 3 családtípus

differenciálására nyújtott lehetôséget: (1) autokratikus („A”), (2)

engedékeny ("M") és (3) kiegyensúlyozott („K”). Eredményeink. számos statisztikailag is jelentôs különbséget igazoltak, melyek

részben a korosztályi sajátosságokkal, részben pedig a családok. tágabb környezetben végbemenó szociális, gazdasági és demográfiai változásaira adott válaszaként értelmezhetóek.

\footnotetext{
A z egyén életének, fejlődésének legfontosabb színtere és elsődleges közössége: a család (Kozma, 2001; Veczkó, 2007). Vélhetően az emberek mindig is családban éltek, hiszen ezen kiscsoport keretei lehetnek a leginkább alkalmasak a humán szükségletek kielégitésére és optimális védelem biztosítására a személy számára. Az idők során a család müködésében komoly átalakulások mentek végbe, amelynek hátterében elsősorban a társadalmi változások és a velük kapcsolatos új kihívások állnak (Novák, 2009), noha az individuális eltérések szerepe is jelentős.
} 
A legnagyobb módosuláson a serdülőkor idején megy keresztül az egyén, ami az őt magába foglaló családrendszer tekintetében is számos változást idéz elő. A fiatal elsajátítja és átalakítja környezetét, megtanulja a felnőttkor szerepeit, kulturális értékeit, etikai normáit és felelősség vállalását, miközben egyre függetlenebbé válik. A pubertáskor végére a fiatal kialakítja saját identitását, melyet Erikson a legfontosabb serdülőkori feladatnak tart (Cole és Cole, 2006). A családtagok közti szoros kapcsolat pedig segíti a gyermek önállósodásának folyamatát, miként az a serdülők kortársi kapcsolatokba történő bevonódásának és más fiatalok rájuk gyakorolt hatásának mértékét is jelentősen befolyásolja (Vajda, 2006; Szányel, 2007).

A gyermekkel foglalkozó pedagógusok számára fontos, hogy mind jobb rálátást nyerjenek a rájuk bízott fiatalok életére. Ismerjék az életkori sajátosságokkal járó változások mibenlétét, hiszen ez a tudás nyit lehetőséget számukra a diákokkal való mind hatékonyabb munkához. A felnövekvő gyermek érzelmi életének, gondolkodási folyamatainak és viselkedésének megismerése tehát nem nélkülözhető tényezők azon szakmákban, ahol fiatalok oktatása-nevelése folyik.

De vajon a gyermekek fejében családjukról formálódó kép hogyan alakul az iskolás évek alatt? Milyen mintákat visznek tovább a fiatalok, amelyek későbbi családjuk kialakításakor alapként szolgának majd számukra? Mennyiben vágynak a kisiskolások és kamaszok családjuk úgymond megváltoztatására, illetve él képzeletükben egy másabb mentális kép családjukról, mint ahogyan azt jelenleg észlelik? Továbbá a megragadható családkép és -ideál egyes komponensei miként viszonyulnak egymáshoz? Kutatásunkban ezt a témát járjuk körül és osztjuk meg az olvasóval vizsgálatunk nyomán nyert tapasztalatainkat, eredményeinket és következtetéseinket.

\section{A család-mint rendszer}

„A családi rendszer fogalma azon a felismerésen alapul, hogy a viselkedésformák szerveződése egy időtengely mentén képzelhető el. Bármely családban a mindennapi élet szerveződése az adott család fennállásának tartalma szerint épül fel, és magába foglalja mindazt, amit a család az előző generáció sémáiból megtanult. Ezen sémák legnagyobb része minden családban a szokásokhoz híven müködik, és a családtagok számára nem tudatos"(Barnes, 2004. 13. o.). Maga a család pedig több mint a rokonok összessége, hiszen olyan egyedi rendszert képez, amelyben a család minden egyes tagja mélyreható, és gyakran rejtett befolyást gyakorol a többiekre (Novák, 2009).

Amikor a családról, mint rendszerről beszélünk, néhány közös, karakterisztikus jegyet meg kell említenünk. A családtagok kölcsönösen hatnak egymásra, minden személy cselekedete bizonyos mértékig a többiekéhez kapcsolódik. Az ismétlődő minták (izomorfiák) jelen vannak mind a viselkedésben, mind pedig a kapcsolatokban. Emellett a család tagjai nagyon hasonló identitástudattal és meggyőződéssel bírnak (Kurimay, 2000).

Miután a gyermek is a családrendszer aktív tagja, hatással van a családra, alakítja annak müködését. Ezzel párhuzamosan a család egésze is visszahat az egyénre. Ezt a körkörösséget cirkularitásnak nevezik, melynek alapját az adja, hogy a család rendszerén belüli hatások egymással összefonódnak, s a lineáris oksággal szemben a jelenségek inkább válnak értelmezhetővé a körkörös/spirális viszonyok alapján (Túry, 2010). A család jellegzetességei viszont nem következtethetők ki egyetlen tagjának tulajdonságaiból sem. A rendszer felépítését az adott tágabb környezet mintáival, szabályaival formálja oly módon, ahogy azt a család értelmezi, sajátjává alakítja (Bagdy, 1994; Dombi, 2013). A család maga tehát kétirányú kapcsolatban van környezetével, információkat szerez, de mintegy védőhálót is képez tagjai számára a környezetből jövő ingerek ellenében (Novák, 2009). 
A család működése éppen úgy lehet optimális, miként diszfunkcionális. Utóbbi gátat szab a gyermek normál fejlődésének, hiszen nem ritkán merev, célszerütlen viselkedési mintákat közvetít. Az ilyen rendszer önmagát zárja le, és erősen védelmezi törékeny belső egyensúlyát. Ennek biztosítása érdekében pedig a család „kitermelheti” valamely tagjának betegségét vagy viselkedészavarát is, ami a többi családtag gyengeségeit vagy személyiséghibáit eltakarja vagy kiegyenlíti. A családon belül azonban gyakran történnek változások, melyek egyúttal a szerepek átalakulását is magukkal hozzák. Idetartozik többek között maga a pubertáskor, a házasság, a nyugdíjba lépés, melyek akár krízishelyzetig is fokozódhatnak, s végső soron akár a család belső szerkezetének összeroppanását is eredményezhetik (Bagdy, 1994).

„Azt, hogy a családban jól vagy hibásan müködő minták jelennek-e meg, az a mögöttes struktúra (vagyis annak tartós, interaktív, szabályállító mintái) és a családi életciklusok során folyton változó körülményekhez való alkalmazkodás rugalmassága szabályozza" (Goldenberg és Goldenberg, 2008. 117. o.). A harmonikusan müködő családban biztosítva van az egymás iránti szeretet, megértés, gyengédség, támogatás, miként az ilyen családi organizáció a konfliktusokat is képes feloldani, feldolgozni, sőt a gyermek számára előnyös kimenetet biztosítani az adott helyzetből (Veczkó, 2007).

\section{Családi életciklusok és az individuum fejlődése}

A család azonban nemcsak a történelem során ment át változásokon, hanem a saját élete folyamán, a rendszer sajátosságaiból adódóan is alakul. Ez pedig a jól működő családok természetes velejárója. A demográfiai történések életciklusokra tagolják a családi müködéseket. Számos felosztás ismert ezekkel összefüggésben. Míg például Barnes (2004) hat szakaszt említ a könyvében, addig Komlósi (1995a) modellje kilenc ciklusra bontva ismerteti a családok sok éven átívelő müködését. Minden életciklusnak megvannak a maga jellemzői és nehézségei (1. táblázat).

1. táblázat: Családi életciklusok (Komlósi, 1995b; Barnes, 2004; Cole és Cole 2006; Novák, 2007)

\begin{tabular}{|c|c|}
\hline A családi életciklus neve & Főbb jellemzök \\
\hline $\begin{array}{l}\text { Készülés a családalapításra } \\
\text { Az új házasok gyermeknélküli „családja” } \\
\text { (várandósság időszaka) }\end{array}$ & $\begin{array}{l}\text { - párválasztási időszak, a közös élet tervezése } \\
\text { - a házaspár együttélése, családalapítás időszaka, ahol a felek } \\
\text { megtanulják az egymáshoz való alkalmazkodást }\end{array}$ \\
\hline $\begin{array}{l}\text { Csecsemős és pici gyermekes család ( } 3 \\
\text { éves korig) }\end{array}$ & $\begin{array}{l}\text { - a gyermek új viszonyokat hoz létre, ami a korábbi párkap- } \\
\text { csolatot megváltoztatja }\end{array}$ \\
\hline Kisgyermekes család (3-6 éves gyermek) & $\begin{array}{l}\text { - a gyermek életében megjelenik az óvodai nevelés, ezzel } \\
\text { együtt az anya visszatér a munka világába, így társas kapcso- } \\
\text { latai kiszélesednek } \\
\text { - a gyermeknek az apával való viszonya megváltozik, egyre } \\
\text { fontosabb szerepet kapnak egymás életében }\end{array}$ \\
\hline $\begin{array}{l}\text { Iskolás (6-14 éves) gyermekek a } \\
\text { családban }\end{array}$ & $\begin{array}{l}\text { - a gyermek egy új, teljesítményelvü közegnek a tagja lesz, s } \\
\text { noha szülei támogatását még erősen igényli, mégis az önálló- } \\
\text { sodási törekvések felerösödése hatják át ezen periódust } \\
\text { - iméntiekkel összefüggésben és az ekkor végbemenö, a család } \\
\text { egészét érintö változások közepette olyan helyzetekben is } \\
\text { megtanulhat a gyermek helytállni, melyekben nincs mögötte } \\
\text { a biztos szülői háttér, támogatás }\end{array}$ \\
\hline $\begin{array}{l}\text { Serdülő (14-18 éves) gyermeket nevelö } \\
\text { család }\end{array}$ & $\begin{array}{l}\text { - a serdülőkor nehéz időszak az egész család számára } \\
\text { - a serdülő életében gyors változások, illetve a fiatal identitá- } \\
\text { sának formálódása zajlanak, melyekkel mind a pubertáskorú } \\
\text { személynek, mind pedig családtagjainak meg kell birkóznia }\end{array}$ \\
\hline
\end{tabular}




\begin{tabular}{|c|c|}
\hline A családi életciklus neve & Föbb jellemzök \\
\hline $\begin{array}{l}\text { A nagykorúvá, fiatal felnőtté vált } \\
\text { gyermeket kibocsátó család }\end{array}$ & $\begin{array}{l}\text { - a felnőtté vált gyermek önállósodása befejeződik és - első- } \\
\text { sorban érzelmileg -leválik a szüleiröl }\end{array}$ \\
\hline $\begin{array}{l}\text { A magára maradt, még aktív szülők } \\
\text { családja }\end{array}$ & $\begin{array}{l}\text { - ismét egygenerációs család jön létre, de más feltételekkel, } \\
\text { mint amikor családot alapítottak } \\
\text { - újabb szerepváltások történnek: anyósok, apósok, majd } \\
\text { nagyszülők lesznek a magukra maradt felek }\end{array}$ \\
\hline Nyugdíjas, inaktív öreg házaspár családja & $\begin{array}{l}\text { - az anyagi korlátok és a fizikai erőnlét csökkenése miatt } \\
\text { beszükülnek a férjnek és a feleségnek az életlehetőségei, } \\
\text { melyet sokan negatívan élnek meg } \\
\text { - lehetősége nyílik az idős személyeknek megvalósítani azokat } \\
\text { a céljaikat, amelyeket munkájuk miatt eddig nem állt mód- } \\
\text { jukban elérni }\end{array}$ \\
\hline
\end{tabular}

A család életciklusai és Erikson pszichoszociális fejlődést nyomon követő elmélete jól kirajzolódó párhuzamokat mutatnak, melyeket az alábbiakban foglaltunk össze (2. táblázat).

2. táblázat: A családi életciklusok és az egyén pszichoszociális fejlődésének (Erikson-féle) párhuzamai (Erikson, 1991; Komlósi, 2000. nyomán)

\begin{tabular}{|c|c|c|c|c|c|}
\hline & $C S A L A ́ D$ & & $E G Y E ́ N$ & $\begin{array}{c}\text { A konfliktus két pólusa és az adott } \\
\text { szakaszra jellemzö hajtóerö }\end{array}$ & életév \\
\hline 1. & Házasságkötés & & & & \\
\hline \multirow[t]{2}{*}{2.} & \multirow[t]{2}{*}{$\begin{array}{l}\text { Csecsemős és kis- } \\
\text { gyermekes család }\end{array}$} & I. & $\begin{array}{l}\text { A csecsemő és az elis- } \\
\text { mertség kölcsönössége }\end{array}$ & $\begin{array}{l}\text { bizalom vs. bizalmatlanság } \\
\rightarrow \text { remény }\end{array}$ & -1 \\
\hline & & II. & $\begin{array}{l}\text { A korai gyermekkor és a } \\
\text { „légy önmagad” akarata }\end{array}$ & $\begin{array}{l}\text { autonómia vs. szégyen } \\
\rightarrow \text { akarat }\end{array}$ & $1-2,5$ \\
\hline 3. & $\begin{array}{l}\text { Óvodás gyermekes } \\
\text { család }\end{array}$ & III. & $\begin{array}{l}\text { A gyermekkor és a } \\
\text { szerepek előlegezése }\end{array}$ & $\begin{array}{l}\text { kezdeményezés vs. büntudat } \\
\rightarrow \text { szándék }\end{array}$ & $2,5-6$ \\
\hline 4. & $\begin{array}{l}\text { Iskolás gyermek a } \\
\text { családban }\end{array}$ & VI. & $\begin{array}{l}\text { Az iskoláskor és a fel- } \\
\text { adattal való azonosulás }\end{array}$ & $\begin{array}{l}\text { teljesítmény vs. kisebbrendủség } \\
\rightarrow \text { kompetencia }\end{array}$ & $6-12$ \\
\hline 5. & $\begin{array}{l}\text { Serdülő gyermeket } \\
\text { nevelő család }\end{array}$ & V. & Serdülökor & $\begin{array}{l}\text { identitás vs. identitászavar, sze- } \\
\text { repkonfúzió } \\
\rightarrow \text { hüség }\end{array}$ & $12-20$ \\
\hline 6. & $\begin{array}{l}\text { Felnövekedett gyer- } \\
\text { meket kibocsátó } \\
\text { család }\end{array}$ & VI. & Korai felnőttkor & $\begin{array}{l}\text { intimitás vs. izoláció } \\
\rightarrow \text { szeretet }\end{array}$ & $20-40$ \\
\hline 7. & $\begin{array}{l}\text { Magukra maradt, } \\
\text { még aktív szülők }\end{array}$ & VII. & Felnőttkor & $\begin{array}{l}\text { generativitás, alkotóképesség vs. } \\
\text { stagnálás, megrekedés } \\
\rightarrow \text { gondoskodás }\end{array}$ & $40-65$ \\
\hline 8. & $\begin{array}{l}\text { Inaktív öreg házaspár } \\
\text { családja }\end{array}$ & VIII. & Időskor & $\begin{array}{l}\text { énintegritás vs. kétségbeesés } \\
\rightarrow \text { bölcsesség }\end{array}$ & $65-$ \\
\hline
\end{tabular}

Azonban az individuum fejlődésére és a családi életciklusokra nézve ismert egy komplex modell is, melyben iméntieket egymásba ágyazva láthatjuk (1. ábra). Az ábrán az arab számok a családi ciklusokat mutatják, a római számok pedig az individuum fejlődését segítenek nyomon követni (Bagdy és Mirnics; 2006). 


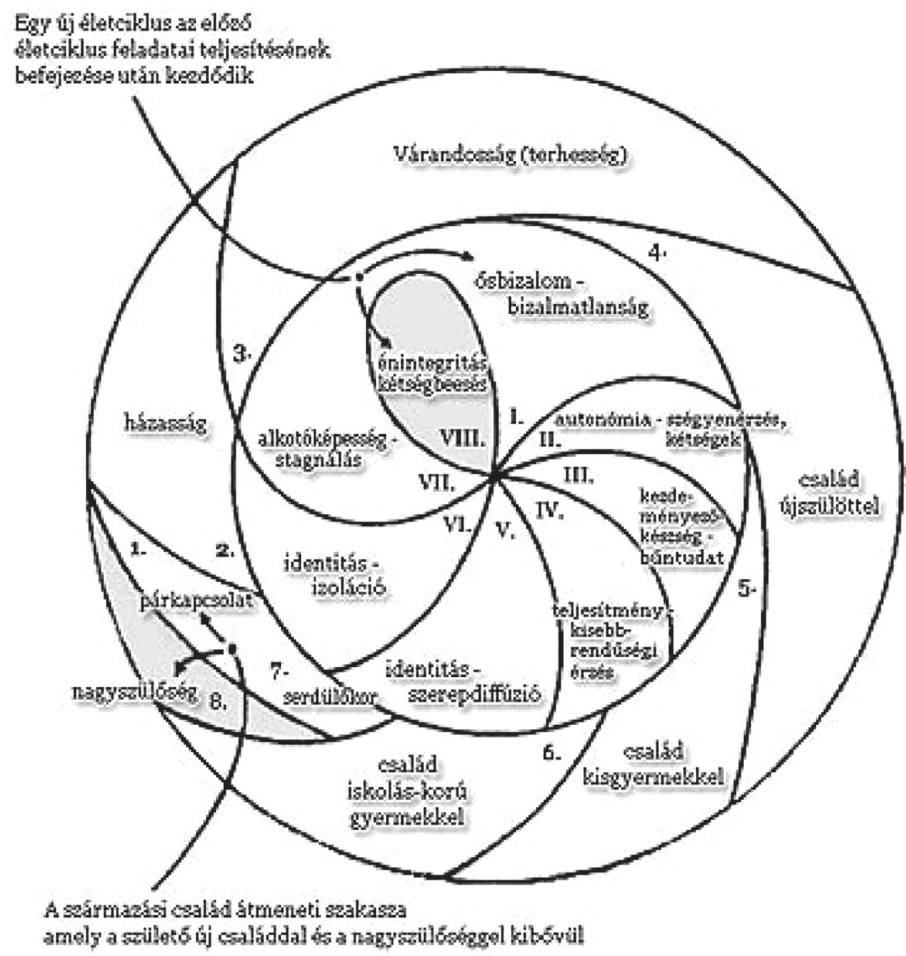

1. ábra: Erikson pszichoszociális fejlödésnél leirt nyolc szakaszának a családi életciklusokkal való összefüggése (Kurimay nyomán, 2004; készitette: Bagdy és Mirnics 2006)

\section{Iskolás (6-14 éves) gyermek a családban}

A 6. életév számos változást hoz a gyermek életében. Az iskolába járás, az otthoni feladatok elvégzése immár társadalmi kötelezettséggé válnak (Komlósi, 1995b). Iskolába kerülésével a gyermek egy új közegnek a tagja lesz, ahol egyre tudatosabban alakítja kapcsolatait. Az eddig tanult mintákat itt próbálja ki, és érvényesíti kompetenciáit. Az iskola a gyermeket egy teljesítményelvű világba vezeti be, ahol a mindennapokban folyamatosan versenyhelyzetbe kerül a fiatal, melynek során sikerei és kudarcai hatást gyakorolnak a személyiségére. Az iskolai teljesítmény mellett a gyerekek közötti kapcsolat formálódása a család életére is kihatással. A kortársaival optimális viszonyt kialakító fiatal esetében ugyanis a szülöknek hamarosan szembe kell nézniük azzal, hogy a családon kívüli kapcsolati rendszer egyre fontosabb szerephez jut a gyermek életében. Ilyenkor pedig komoly jelentőségre tesz szert, hogy a szülők miként reagálnak a fiatal magatartására. Hiszen az idősebb generáció támogatásával érheti el a gyermek, hogy egyre önállóbbá váljon, amely viselkedés hatékonyan segíti majd őt a felnőtté válás folyamatában, a hétköznapok kihívásaival való megküzdésben.

$\mathrm{S}$ noha ebben a periódusban a fiatal önállósodási törekvései mindinkább kezdenek kibontakozni, mégis fontos látnunk, hogy a prepubertás korban lévő gyermek még mindig nagyon igényli szülei támogatását, illetve azt, hogy ők elérhetők legyenek a számára. Nehézséget okoz, ha a szülők nem tudnak mit kezdeni a serdülőkorhoz közelítő gyermek magatartásbeli változásával. Ebből adódóan ugyanis a gyermek nehezített helyzetbe 


\section{Nehézséget okoz, ha a szülók} nem tudnak mit kezdeni a serdülókorhoz közelítô gyermek magatartásbeli változásával. Ebból adódóan ugyanis a gyermek nehezitett helyzetbe kerül: hangulati hullámzásai, a környezetében bekövetkezó konfliktusok, a szülók úgymond meg nem értése, mind-mind oda vezetnek, hogy a felnóttek világától elszigetelódik, bizalmi kapcsolatait leginkább kortársaival ápolja, támogatást és megerôsitést, újonnan születố érzéseihez és gondolataihoz (baj)társakat keresve (Komlósi, 1995b).

kerül: hangulati hullámzásai, a környezetében bekövetkező konfliktusok, a szülők úgymond meg nem értése, mind-mind oda vezetnek, hogy a felnőttek világától elszigetelődik, bizalmi kapcsolatait leginkább kortársaival ápolja, támogatást és megerősítést, újonnan születő érzéseihez és gondolataihoz (baj)társakat keresve (Komlósi, 1995b). Ez pedig könnyen lehet, hogy a szükséges, kizárólag a felnőttektől elnyerhető támasz elmaradását is magával hozza.

\section{Serdülő (14-18 éves) gyermeket nevelő család}

A serdülőkor az egész család számára kiemelten nehéz időszak, amikor a szülőknek változniuk kell gyermekükkel való kapcsolatukon. Az addig fenntartott aszimmetrikus viszony helyett immár szimmetrikusabb kapcsolat létrehozása válik szükségessé. Ez viszont számos esetben nehézségekbe ütközik. A szülők ugyanis rendszerint nem szeretnék a kapcsolat irányítását átengedni a kamasznak, hanem inkább törekednének a korábbi aszimmetrikus viszony fenntartására, ami komoly konfliktusokhoz vezethet a családban (Komlósi, 1995b).

De mi is történik ebben az időszakban a fiatallal? A serdülö gyermek életében - miként ezt a korábbiakban is már láttuk - gyors és nehéz változások mennek végbe, melyekkel összefüggésben nem vagy csak nagyon ritkán kérnek segítséget a fiatalok, rendszerint azt sem a szüleiktől. Hiszen például a másodlagos nemi jellegek alakulása során megnyilvánuló látványos fizikai változások magát a serdülőt is zavarba hozzák, így könnyebb lehet a kortársak felé orientálódás, a hasonló nehézségekkel küzdő fiatalokkal történő problémamegosztás, mint egy felnőttnek mondani el, hogy „mi fáj”. Mindehhez hullámzó kedélyállapot, csapongó fantázia és növekvő önállósági törekvés társul amelyek tovább mélyítik a tekintett életkorban átélt nehézségeket, a velük történő megküzdés problematikáját, ezáltal is növelve a felnőttekkel való összeütközések kockázatát (Novák, 2009).

Az első családról való leszakadási kísérletek is ezen időszakra tehetőek, amelyek nem ritkán érzelmi-, illetve fizikai szeparációhoz vezetnek. A serdülők mind önmagukat, mind családjukat illetően rendkívül kritikusak, némi távolságból szemlélik a felnőttek világát. Bár a felnőttek mintaadására nézve még várakozással néznek, de már partneri kapcsolatban érzik ezt hitelesnek, ilyen formán érhetjük el őket a leginkább. A kompetencia viszonyok is megváltoznak a családon belül. A fiatalok jobban igénylik, hogy beleszólhassanak a családi ügyekbe és véleményük meghallgatásra találjon a különböző döntési helyzeteknél. A korábban elfogadott hatalmi viszonyok ellen eröteljesen lázadnak a korosztály tagjai, hiszen azt szeretnék, hogy végre felnőttként kezeljék őket.

Miközben a fiatalok érettsége még több területen is hiányosságokat mutat, a családnak mégis felnőttként kell kezelnie a gyermeket, hogy megóvja őt elhamarkodott döntéseinek, átgondolatlan tetteinek akár jóvátehetetlen következményeitől és az egyéb negatív hatásoktól (Novák, 2009). 
A tanulmány keretében vizsgált két korosztály (kisiskolás- és serdülőkor) pszichoszociális és kognitív fejlődése sajátosságainak és az adott családi életciklusra jellemző főbb tulajdonságok áttekintésére szolgál a 3. táblázat.

3. táblázat: A gyermek pszichoszociális és kognitiv fejlödése, valamint a családi életciklusok

\begin{tabular}{|c|c|}
\hline Kisiskoláskor & Serdülökor \\
\hline $\begin{array}{l}\text { - Konfliktus: teljesítmény vs. kisebbrendűség } \\
\text { - Hajtóerő: kompetencia (Cole és Cole, 2006) }\end{array}$ & $\begin{array}{l}\text { - Konfliktus: identitás vs. identitászavar, szerepkon- } \\
\text { fúzió } \\
\text { - Hajtóerő: hűség (Cole és Cole, 2006) }\end{array}$ \\
\hline - Konkrét müveleti szakasz (Cole és Cole, 2006) & - Formális műveleti szakasz (Cole és Cole, 2006) \\
\hline $\begin{array}{l}\text { - Két időszak differenciálható: } \\
\text { 1. Kezdeti, higgadtabb szakasz (9-10 év) } \\
\text { 2. Nyugtalanabb, érzékenyebb szakasz (10-12 év) } \\
\text { - A biztos szülöi szeretet és annak megnyilvánu- } \\
\text { lásai fokozott jelentőséggel bírnak a gyermek } \\
\text { alakuló, formálódó identitására, } \\
\text { - a testvérkapcsolat (szolidaritás terén) általában } \\
\text { rendeződik, } \\
\text { - a szülök párkapcsolati problémái inkább a fel- } \\
\text { színre törhetnek (válás) (Kármán, 2004). }\end{array}$ & $\begin{array}{l}\text { - Két időszak differenciálható: } \\
\text { 1. Individualizáció időszaka lásd: „,honnan?” } \\
\text { (12-16/17 év) } \\
\text { 2. Jövőorientáció és újraközeledés lásd: „hová?” } \\
\text { („,megbocsátó magatartás”) }(17-18 / 19 \text { év) } \\
\text { - A viselkedés kiegyensúlyozatlansága és hangulati } \\
\text { ingadozások, } \\
\text { - a kortárskapcsolatok megnövekedett jelentősége, } \\
\text { - a szülők felháborodása, tehetetlensége a gyermek } \\
\text { megváltozott magatartása felett (Kármán, 2004) }\end{array}$ \\
\hline
\end{tabular}

\section{A családkép megismerésének eszközei}

A családok müködéséről számos eszköz segítségével gyüjthetünk információt. Hazai és nemzetközi szinten a legismertebb eszközök a következők:

1. Olson és Gorall (2003) Családtesztje [legújabb változat: FACES IV., hazai adaptáció (OCST-4): Vargha, Baktay, Tóth, Kisgyörgyné és Bagdy (2006)],

2. Gehring (2010) Családstruktúra tesztje (FAST),

3. valamint a Közös Rorschach Vizsgálat (KRV), melyet elsőként Loveland, Wynne és Singer (1963) alkalmaztak, s amely eszköz hazai adaptációját és első jelölőrendszerét Bagdy, Kósa és Safir (2002) alakították ki, felismerve az abban rejlö lehetőségeket.

Az első eszköz egy kérdőív, amely a családok müködését -a korábban végzett több kutatás metaanalízise nyomán - három dimenzió mentén írja le: kohézió, flexibilitás és kommunikáció. Hat családtípus differenciálására (adaptív: összetartó és rugalmas, inadaptív: széteső, egybefonódott, kaotikus és merev) alkalmas, ami mellett lehetőséget biztosít a „családdal való elégedettség”(CSES skála) és „családi kommunikáció” (CSKS skála) révén a családtagok közti kapcsolat és a rendszer általános funkcionálási színvonalának a megismerésére (Olson és Gorall, 2003; Vargha és mtsai, 2006; Vargha és Tóth, 2007).

A második eszköz egy projektív módszer, amely - az előzővel szemben - már az alrendszerek szintjén megmutatkozó kapcsolati struktúrák feltárására is alkalmas. Emellett a vizsgálati személy - a teszt jellegéből adódóan - hitelesebb képet tár elénk családjáról, illetve azzal kapcsolatos reprezentációiról. Itt ugyanis kis fabábuk segítségével történik meg a családtagok viszonyrendszerének ábrázolása, melyet egy táblán végez el az egyén (kohézió dimenzió). Ezt követően pedig a dominanciaviszonyok megjelenítésére kerül sor (hierarchia dimenzió). A nevezett két faktor mentén három családtípust különböztetünk meg: kiegyensúlyozott, labiliskiegyensúlyozott és kiegyensúlyozatlan. A kvalitatív analízishez kapcsolódóan a családtagok személyes tulajdonságai opcionálisan színekkel kerülhetnek kiemelésre. A három lehetséges kirakásból (tipikus helyzet, ideális helyzet és konfliktusos helyzet) a kísérletvezető választ, 
hogy melyike(ke)t kéri a vizsgálati személytől, kutatási céljának függvényében. A családról alkotott mentális reprezentációk demonstrációját követően félig strukturált interjú segíti a kirakások, eredmények alanyi értelmezését. Ez a projektív módszer tehát a kvantitatív és kvalitatív elemzés lehetőségére egyaránt lehetőséget biztosít (Gehring, 2010; Kékes Szabó, 2013).

Harmadik eszközként pedig egy igen figyelemreméltó, a párok vagy családok müködésébe (kommunikáció, dominanciaviszonyok, affektív kapcsolódások, illetve a vizsgált személyek kooperációs magatartása) belátást engedő eljárás még a Közös Rorschach Vizsgálat (KRV). Az eljárás egy speciális döntési helyzet indukálásával ugyanis együttmüködésre, de legalább is interakcióra készteti a személyeket, miáltal transzparenssé válnak a rendszerben fennálló kapcsolatok, jól interpretálhatóvá téve az organizációs sajátosságokat (Bagdy, 2002; Bende, Radnai, Habis és Mirnics, 2007).

\section{Empirikus előzmények}

A serdülőkor idején a fiatalok családképe (kohézió és hatalmi viszonyok) változásokon megy keresztül. Ez két dologban ragadható meg: (1) a szülőktől való relatíve nagyfokú függőséget kiegyensúlyozott(abb) kapcsolat váltja fel, ami lehetőséget biztosít a fiatal önállósodására. (2) Továbbá a szülők relatíve egyoldalú dominanciája helyett mindinkább a kölcsönösségen alapuló kapcsolatok lesznek jellemzőek (Youniss és Smollar, 1985).

Gehring, Marti és Sidler (1994) prepubertás korú gyermekek családreprezentációinál tipikus helyzetben kiegyensúlyozott (összetartó és mérsékelten hierarchikus), konfliktusos helyzetben pedig túlnyomórészt kiegyensúlyozatlan családstruktúrát tártak fel.

Feldman és Gehring (1988) 6., - 9. és - 12. évfolyamos diákok családreprezentációit hasonlították össze. Eredményeik az idősebb korosztálynál, az ideális családképpel összefüggésben, szorosabb kapcsolati viszonyokat és hasonló/mérsékeltebb hierarchiát igazoltak (a szülők dominanciája azonban minden korosztálynál fennállt).

Kékes Szabó (2013) fiatal felnőtteknek az ideális helyzetre vonatkozó családreprezentációjánál- az iménti kutatással összhangban - a kiegyensúlyozott családstruktúrák nagyobb arányú előfordulását találta, ami a családon belüli közepes/magasabb szintü kohézió és közepes szintü hierarchia dimenziókat jelzi.

Az ideális családkép valósággal történő összehasonlítása pedig egyfelöl a családstruktúra rugalmasságáról (adaptivitásáról) vall (Gerber és Kaswan, 1971; Noller és Callan, 1986), másfelől pedig a családi kapcsolatokkal való elégedetlenségre utalhat (Cromwell és Peterson, 1983; Olson, 1986).

Más vizsgálatok szélesebb kontextusban tekintették át a családi müködéseket és tagjainak rendszerről való elgondolásait. Így például Kötters, Krüger és Brake (1996) 10- 17 éves fiatalok önállóságát, a szülői befolyást, a konfliktusok és a családi légkör alakulását tekintették. Eszerint bár a fiatalok - a serdülőkorból adódó aktuális konfliktusos helyzetek ellenére - alapvetően harmonikusnak ítélték családjuk müködését, a családi légkör pozitív megítélése a pubertáskortól (egészen pontosan a 13. életévtől) fokozatosan romlott. Amennyiben a gyermekek úgy érezték, hogy problémáikkal kevésbé fordulhatnak szüleikhez, avagy kérhetnek tölük tanácsot, úgy ez a tendencia markánsabban jelentkezett. Tehát a családon belüli kommunikációs problémák a rendszeren belüli kedvezőtlen légkör észlelésének „élményét”erősítették (Kasten, 2004).

A serdülők márpedig hajlamosak kritikusabban megítélni a dolgokat, ami a családi organizáció és kommunikáció szempontjából is fennáll. Ez pedig a fiatalok családdal való elégedettségére is hatást gyakorol. Figyelemreméltó, hogy az egyes családtagok rendszerről és annak müködéséről szóló elképzelései között milyen komoly eltérések 
mutatkoznak (Barnes és Olson, 1985; Noller és Callan, 1986; Gehring, Marti és Sidler, 1994). Ami viszont egészen biztosan elősegíti az adaptív családi müködést, az a szülők közti szoros érzelmi kapcsolat (Feldman és Gehring, 1988).

\section{Célkitúzéseink, hipotéziseink}

Kutatásunk célja a kisiskolás- és serdülőkorú fiatalok által valós helyzetben észlelt és ideális helyzetre vonatkozóan elgondolt családképének megismerése, összehasonlítása, $\mathrm{s}$ ezáltal a különbségek feltárása volt.

Kutatási kérdéseink a következők szerint kerültek megfogalmazásra:

1. Hogyan alakul a kisiskolások és a serdülők az észlelt és az ideális családról alkotott képe?

2. Milyen különbségek mutatkoznak az észlelt és az ideális családkép egymáshoz való viszonyában a tekintett korosztályoknál?

3. Hogyan alakul a különböző családtípusok megoszlása a két korcsoportban, a vizsgált két helyzetre vonatkozóan?

Az iménti kutatási kérdések mentén pedig hipotéziseink a következők voltak:

1. Mind az észlelt, mind az ideális családkép esetén az alsósok pozitívabban ítélik meg családjukat, mint a serdülők. Tehát a fiatalabb gyermekek várhatóan szorosabb (de nem összefonódásra utaló) érzelmi kapcsolatokról és közepes szintü családon belüli hatalmi viszonyokról adnak számot, miként magasabb szintű családi adaptivitásról is vallanak.

2. A serdülőknél - figyelembe véve a korosztályra jellemző kritikusabb, önállóságra törekvő viszonyulást a körülöttük lévő dolgok, történések irányába - az észlelt és az idealizált családkép között nagyobb eltérések fognak mutatkozni, mint a kisiskolás gyermekeknél.

3. A kisiskolásoknál a jelen és az ideális helyzetekre nézve is kiegyensúlyozottabb, a gyermekek szemszögéből nézve jobban funkcionáló családtípusok határozhatóak meg. Ezzel szemben, föként az észlelt családra vonatkozóan, a serdülök inkább kiegyensúlyozatlannak találják családjukat, miáltal válaszaik nyomán - a diszfunkcionális családtípusok nagyobb arányú előfordulása mutatkozhat.

\section{Kutatás}

\section{Résztvevök}

Vizsgálatunkba 3. osztályos (kisiskolás) (életkor: 8-11 év, M: 9,286, SD: 0,607, 24 lány/25 fiú) és 9. osztályos (serdülők) (életkor: 14-16 év, M: 15,25, SD: 0,52, 37 lány/ 11 fiú) gyermekek/fiatalok kerültek bevonásra, akik mind szegedi oktatási intézmények diákjai. A személyek szocioökonómiai státusza - a feltárt információk alapján - hasonló képet nyújtott. Jellemző módon középosztálybeli, értelmiségi szülők gyermekei tanultak a kutatásnak helyet adó iskolákban. A gyermekek/fiatalok a vizsgálatban érdeklődéssel, szívesen vettek részt. Anyagi vagy egyéb juttatásban nem részesültek az együttmüködésért a tanulók. 


\section{Eszközök:}

A családkép vizsgálatára Mányai (1990) kérdöívét használtuk fel, annak Tóth (2004) „Pszichológiai vizsgálati módszerek a tanulók megismeréséhez” című könyvében „Családkép, családideál” néven elérhető kérdőív formájában. „Az eszköz a családi müködésre vonatkozó családi, illetve egyéni elégedettség mérésére ad lehetőséget a résztvevő szemszögéből értékelve" (Tóth, 2004, 97. o.). Továbbá a módszer a vizsgálatba vont személyek életkori sajátosságaihoz is kiválóan illeszkedik.

A mérőeszköz három dimenzió mentén enged jobb rálátást a családok müködésére: (1) a családi hatalom (például: „Minden családtagnak beleszólása van a nagy családi döntésekbe” vagy „A családtagok kimondják, amit gondolnak”), (2) a kohézió (például: „A családtagok otthon elkerülik egymás” vagy „Könnyebb a problémákat egy kívülállóval megbeszélni, mint a családtagokkal”) és (3) az adaptivitás (például: „A mi családunk új megoldásokat keres a problémákra” vagy „A családtagok megvitatják a problémáikat és mindenkinek tetsző megoldásokhoz jutnak"). Vagyis a családi hatalomra a családon belül hierarchiára enged rálátást, a kohézió keretében a családon belüli érzelmi kötelékeket ismerhetjük meg, míg az adaptivitás dimenzió a családrendszer változóképességét, flexibilitását tükrözi.

Ez a három skála hiteles képet rajzol elénk a vizsgált családról, hiszen a fenti kategóriák kellő mértékben tágak és mégis megfelelő mértékben szükítettek. A 30 kijelentés, melyek a tesztben találhatóak, igen változatosan ragadják meg az egyes dimenziókat, ezzel is finomítva a családról elénk tárt képet.

A tekintett három faktor értelmében pedig három családtípus válik megkülönböztethetővé (4. táblázat).

4. táblázat: Mányai (1990) családtipológia kérdőivének három differenciált családtípusa és azok jellemzői (Tóth, 2004. alapján)

\begin{tabular}{|c|c|c|c|}
\hline \multirow[t]{2}{*}{ A kérdöiv faktorai } & \multicolumn{3}{|c|}{ Családtipusok } \\
\hline & „A" tipus & „M" típus & „K”tipus \\
\hline családi hatalom & $\begin{array}{l}\text { - autokratikusabb hatalmi } \\
\text { viszonyok }\end{array}$ & $\begin{array}{l}\text { - túlzottan engedékeny, } \\
\text { - mindenbe beleszólást } \\
\text { engedő, } \\
\text { - kevésbé határozott } \\
\text { - irányítási stílus és } \\
\text { vezető szerep }\end{array}$ & $\begin{array}{l}\text { kiegyensúlyozottabb, } \\
\text { határokkal tisztában } \\
\text { lévő, alapvetően demok- } \\
\text { ratikus hatalmi felépítés }\end{array}$ \\
\hline kohézió & $\begin{array}{l}\text { - laza kohézió } \\
\text { - szétesésre való hajlam }\end{array}$ & $\begin{array}{l}\text { - erős kohézió, } \\
\text { - összefonódásra való } \\
\text { hajlam }\end{array}$ & $\begin{array}{l}\text { - nem túl erős, de a csa- } \\
\text { ládtagok közti kapcsola- } \\
\text { tot biztosító kohézió, } \\
\text { - ami az egyének autonó- } \\
\text { mia szükségleteit jobban } \\
\text { kielégítheti }\end{array}$ \\
\hline adaptivitás & $\begin{array}{l}\text { - alacsonyabb szintü } \\
\text { adaptivitás, } \\
\text { - feladatok és szerepek } \\
\text { rigidebb elosztásával }\end{array}$ & $\begin{array}{l}\text { - változékony, } \\
\text { - gyengébb stabilitást } \\
\text { engedő } \\
\text { - } \begin{array}{l}\text { szerep- és feladatmeg- } \\
\text { osztás }\end{array}\end{array}$ & $\begin{array}{l}\text { - a feladat- és szerep } \\
\text { kijelölés itt támogatja } \\
\text { a leginkább a családi } \\
\text { struktúrát }\end{array}$ \\
\hline
\end{tabular}

A családtípusok differenciálásának további kritériumai:

- „A” típus: legalább egy skála alacsony és maximum közepes a többi

- „M” típus: legalább egy skála magas és minimum közepes a többi

- „K” típus: mindhárom skála közepes” (Tóth, 2004. 98. o.). 
Tehát míg a diszfunkcionális családoknál szélsőségesebb hatalmi és kohéziós viszonyok állnak fenn, s a családi múködések (feladat- és szerepmegosztás) terén is problematikus képpel szembesülünk, addig a jól funkcionáló családoknál a kérdőív egyes faktorai inkább közepes értéket vesznek fel, ami pedig kiegyensúlyozottabb családképet igazol.

A fentiekben leírtak mellett az ún. családtipológia kérdőív az észlelt család (amilyen most) és az ideális család (amilyennek a kitöltő azt látni szeretné) feltárására is alkalmas, hiszen azt egymás után két példányban töltetjük ki a gyermekekkel/fiatalokkal.

Továbbá az egyes skálákon kapott pontszámok átlagaira, illetve az észlelt és az ideális családi helyzetben mért adatok különbségeire nézve is közöl Mányai (1990) eredményeket, a 10-14 éves korosztályra vonatkozóan (5. táblázat).

5. táblázat: Mányai (1990) adatai a családtipológia kérdőivhez kapcsolódóan (Tóth, 2004. nyomán)

\begin{tabular}{|l|c|c|c|}
\hline \multicolumn{1}{|c|}{ Skála neve } & $\begin{array}{c}\text { Átlagp és szórásértékek } \\
\text { (észlelt család) }\end{array}$ & $\begin{array}{c}\text { A változtatás igénye } \\
\text { (észlelt- és ideális család- } \\
\text { képnél mért különbség) }\end{array}$ & $\begin{array}{c}\text { Atlagok és szórásértékek } \\
\text { (ideális család) }\end{array}$ \\
\hline családi hatalom & $32,46(5,61)$ & 4,3 átlag & 36,76 \\
\hline kohézió & $41,50(5,97)$ & 1,9 átlag & 43,4 \\
\hline adaptivitás & $37,95(5,75)$ & 4,5 átlag & 42,45 \\
\hline
\end{tabular}

\section{Eljárás}

A kérdőívek kitöltése előtt felvettük a kapcsolatot az intézmények vezetőivel, majd az osztályfönökökkel megtörtént az időpontok egyeztetése. Az adatfelvételkor jelen lévő első szerző a kutatásban résztvevő diákokat tájékoztatta a kérdőívvel kapcsolatos tudnivalókról. Ezután az osztályban kiosztották a kérdőíveket, majd megkérték a gyermekeket, hogy nézzék át a lapokon olvasható állításokat. A felmerült kérdésekre ezt követően válaszokat kaphattak, ügyelve arra, hogy azok ne befolyásolják majd sem a kérdezőt, sem pedig a többi kitöltőt a válaszadásban. A kérdőívek kitöltése anonim módon történt.

Az adatok statisztikai elemzésekor az SPSS 15.0 for Windows Evaluation Version programszoftvert használtuk. Az analízis során a következö statisztikai próbákat végeztük el:

\section{Eredmények}

$\mathrm{Az}$ eredmények részletesebb ismertetése hipotéziseink mentén történik. Első hipotézisünk bizonyítására, avagy elvetésére tehát a két korosztály által észlelt, majd pedig ideálisként elgondolt családképhez kapcsolódva a kérdőív három dimenziójában nyert átlagértékek összehasonlítását végeztük el.

Az észlelt családkép vonatkozásában elvégzett Független mintás T-próba révén megállapítható, hogy a két vizsgált alminta között szignifikáns eltérés csupán egy dimenzió, a családi kohézió tekintetében mutatkozott $[\mathrm{t}(95)=-2,832, \mathrm{p}=0,006]$. A hatalom dimenzió $[\mathrm{t}(95)=-0,922, \mathrm{p}=0,359]$ és az alkalmazkodóképesség faktorban $[\mathrm{t}(95)=1,617, \mathrm{p}=0,109]$ statisztikailag értékelhető, szignifikáns eltérés nem nyert igazolást. A két korcsoportban kapott eredményeket a következő diagramon szemléltetjük az olvasóval (2. ábra). 


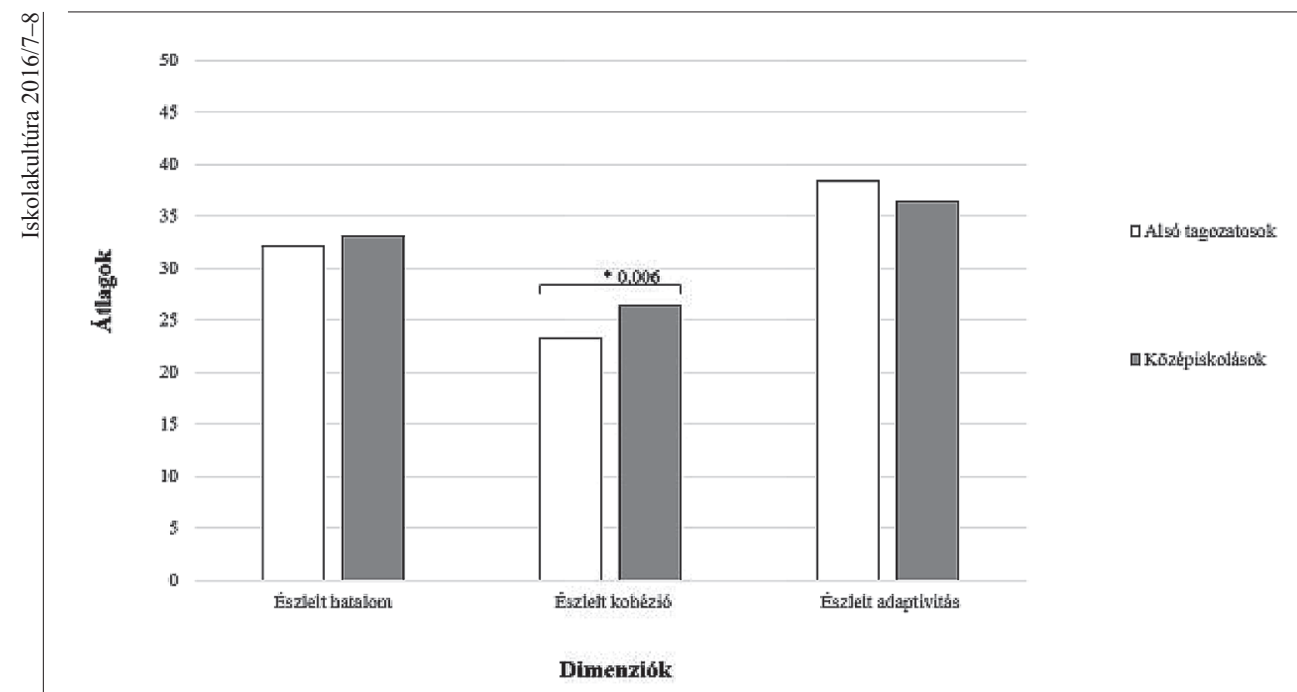

2. ábra: Az észlelt családkép alakulás a két almintán

A serdülők tehát szorosabbnak érzékelik családjuk érzelmi kapcsolatrendszerét. Emellett - noha nem szignifikáns különbséggel - erőteljesebbnek ítélik családjuk hierarchiaviszonyait, míg alacsonyabb szintünek családjuk alkalmazkodóképességét, mint ezt az alsó tagozatosok tették.

Mányai (1990) egyes skálákon kapott pontszámaihoz viszonyítva pedig azt láthatjuk, hogy míg a hatalom és adaptivitás skálákon mindkét korosztály hasonló eredményeket ért el, a kohézió tekintetében nagyfokú eltérés áll fenn. A jelen tanulmányhoz kapcsolódó kutatásba bevont gyermekek, fiatalok ugyanis sokkal alacsonyabb fokú kohézióról adtak számot, mint azt korábban Mányai (1990) vizsgálati személyei tették.

Az ideális családkép esetében egyik dimenzió mentén sem igazolódott szignifikáns eltérés az alsósok és a középiskolások relációjában [hatalom: $(\mathrm{t}(95)=0,154, p=0,877)$, családi kohézió: $(\mathrm{t}(95)=-1,815, \mathrm{p}=0,074)$ és adaptivitás: $(\mathrm{t}(95)=-0,950, \mathrm{p}=0,344)]$. A következő diagramon az ehhez kapcsolódó eredményeket látjuk (3. ábra).

Noha a három dimenzióra nézve nem mutatkozik markáns eltérés, mégis azt a tendenciát látjuk, hogy a serdülők a kohézió és adaptivitás dimenziókban is magasabb értékeket jelöltek meg, mint a kisebbek. Vagyis a serdülők egy kicsit szorosabb érzelmi kapcsolatokat és nagyobb alkalmazkodóképességet szeretnének megélni családjukban, mint az alsó tagozatosok.

Mányai (1990) egyes skálákon kapott pontszámaihoz viszonyítva pedig azt láthatjuk, hogy vizsgálati személyeink nem csupán a valós helyzetre nézve, de ideális családjuk tekintetében is különösen mérsékelt szintü kohéziót írtak le (az átlagértéket tekintve csaknem 50\%-os csökkenést mutatva), mint ezt a referenciamunkánál olvashattuk. A családon belüli hatalom és adaptivitás értékei azonban Mányai (1990) eredményeivel szinkronban voltak.

Az 6. táblázat a kérdőívek kiértékelése során nyert átlag- és szórásértékekről (zárójelben megadva) tájékoztat bennünket, míg a 4. ábra összesítve is megmutatja a kisiskolások és serdülök az észlelt és az ideális családról alkotott képével összefüggésben, a három dimenzióban nyert eredményeket. 
Kovács Nóra - Kékes Szabó Marietta: Családkép és családideál napjainkban

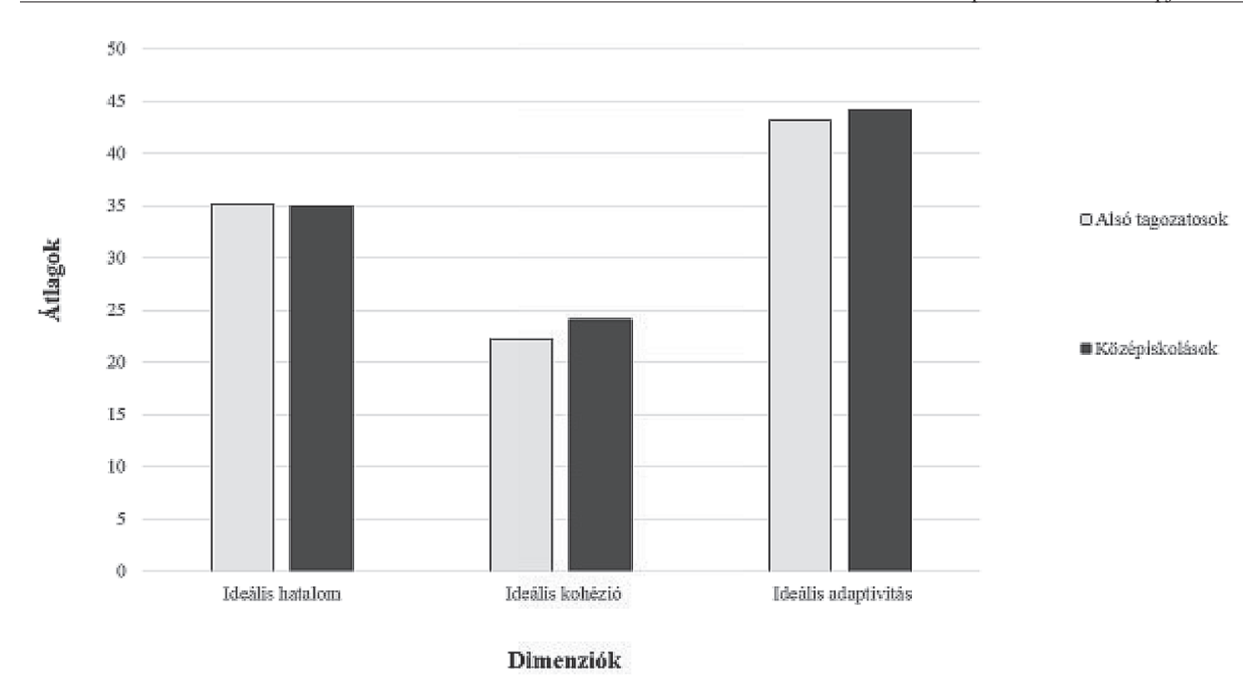

3. ábra: Az ideális családkép alakulása a két almintán

6. táblázat: Átlag-és szórásértékek alakulása az észlelt és az idealizált családképnél, a két almintára nézve

\begin{tabular}{|l|c|c|c|c|}
\hline & \multicolumn{2}{|c|}{ Alsó tagozatosok } & \multicolumn{2}{c|}{ Középiskolások } \\
\hline & Észlelt családkép & Ideális családkép & Észlelt családkép & Ideális családkép \\
\hline Családi hatalom & $32,102(5,459)$ & $35,102(7,122)$ & $33,104(5,236)$ & $34,917(4,375)$ \\
\hline Kohézió & $23,225(4,556)$ & $22,245(3,977)$ & $26,354(6,218)$ & $24,104(5,94)$ \\
\hline Adaptivitás & $38,306(5,796)$ & $43,122(6,707)$ & $36,396(5,837)$ & $44,208(4,247)$ \\
\hline
\end{tabular}

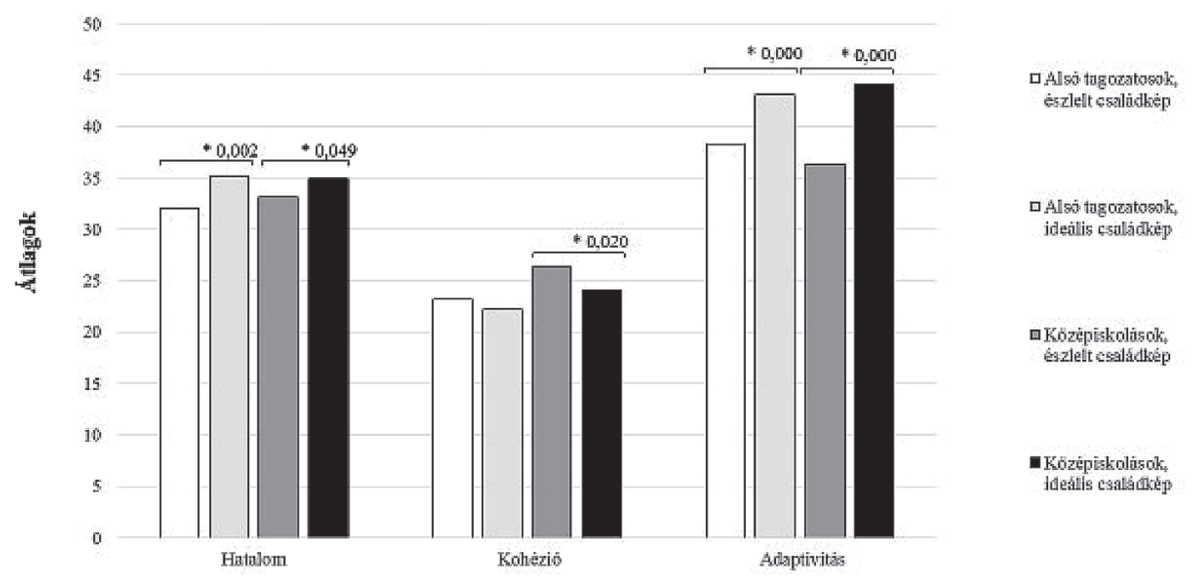

Dimenziök

4. ábra: Az észlelt és az ideális családkép alakulása a két almintán 
Második hipotézisünk bizonyítására, avagy elvetésére külön-külön vizsgáltuk az egyes korosztályokat és hasonlítottuk össze a kérdöív három dimenziójában nyert átlagértékeket az észlelt és az ideális családképre nézve.

Eszerint az elvégzett Páros mintás T-próba az alsó tagozatosok esetében kettő dimenzió mentén tárt fel szignifikáns különbséget: a hatalom esetében [t(48)=-3,196, p=0,002] és az adaptivitásnál $[\mathrm{t}(48)=-4,899, \mathrm{p}=0,000]$. A kohézió dimenzióban $[\mathrm{t}(48)=1,382$, $\mathrm{p}=0,173]$ szignifikáns eltérés nem mutatkozott. Az alsósok eredményeit a következő ábra teszi szemléletesebbé (5. ábra).

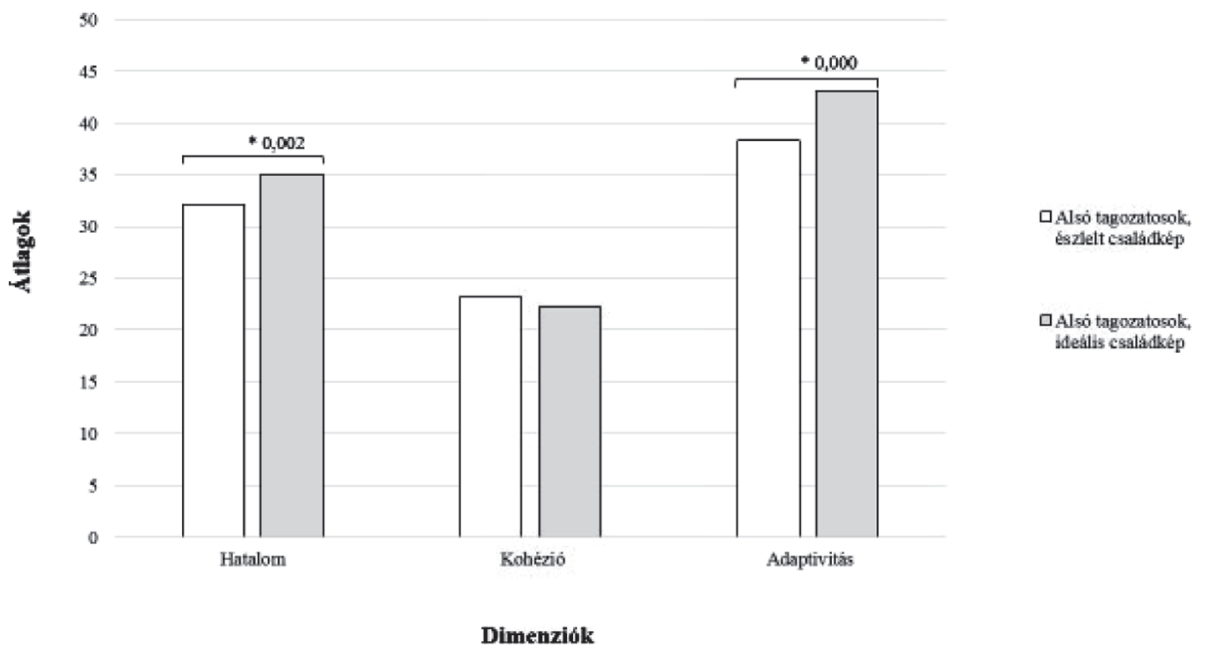

5. ábra: Alsó tagozatosok az észlelt és az ideális családképre vonatkozó eredményei

A kisiskolás korosztály tehát hierarchikusabb, adaptívabb, ugyanakkor mérsékelt kohézióval bíró családot idealizált.

A középiskolásoknál mind a három dimenzióban szignifikáns eltérés mutatkozott, vagyis a hatalom $[\mathrm{t}(47)=-2,017, \mathrm{p}=0,049]$, a kohézió $[\mathrm{t}(47)=2,406, \mathrm{p}=0,020]$ és a családi adaptivitás területén $[\mathrm{t}(47)=-8,763, \mathrm{p}=0,000]$ egyaránt statisztikailag értékelhetö különbségek voltak. Az eredményeket a következőkben mutatjuk be (6. ábra).

Az egyes dimenziókban nyert pontszámok viszonya a kisiskolásokéhoz hasonlóan alakult. A serdülők is alkalmazkodó képesebb, csökkent kohézióval rendelkező, ugyanakkor hierarchikusabb családot idealizáltak.

Az 7. táblázat az alsó tagozatosoknál és a középiskolásoknál, az észlelt és az ideális családkép relációjában kapott átlag-, valamint szórásértékek különbségeiről (zárójelben megadva) tájékoztat bennünket, míg a 7. ábra oszlopdiagramjai mindezt vizuálisan is elénk vetítik. Szignifikáns eltérés az adaptivitás $[\mathrm{t}(95)=-2,255, \mathrm{p}=0,026]$ tekintetében mutatkozott, a többi dimenzióban markáns különbség nem volt megfigyelhető. 


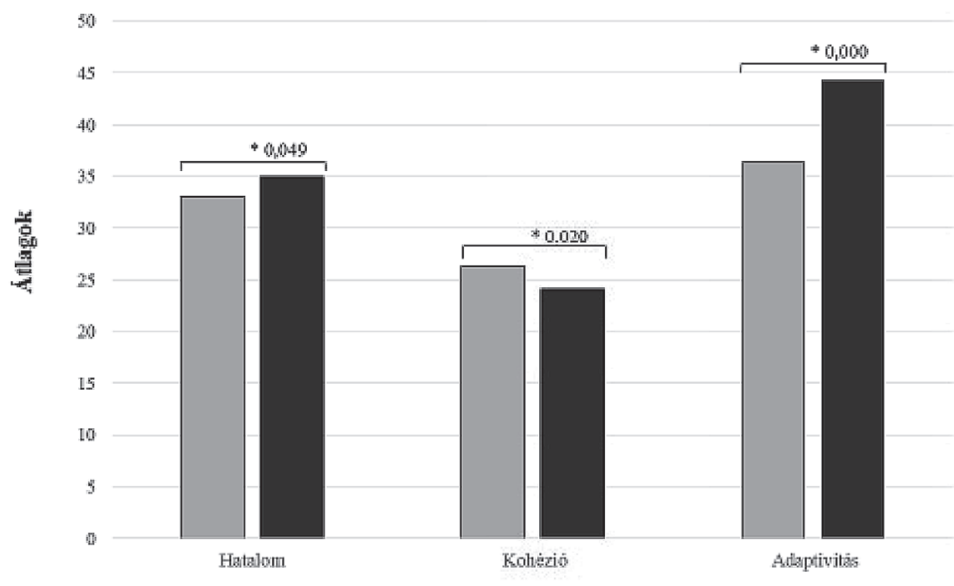

口Köxejpiskolasok, Eंrlalt csalatidkep

更 Koxépiakolisok, idealls csalídilép

Dimenziơlk

6. ábra: Középiskolások az észlelt és az ideális családképre vonatkozó eredményei

7. táblázat: Átlag-és szórásértékek különbségeinek alakulása az észlelt és az ideális családképnél, a két almintára nézve

\begin{tabular}{|l|c|c|}
\hline & Alsó tagozatosok & Középiskolások \\
\hline Családi hatalom & $3(6,57)$ & $1,813(6,225)$ \\
\hline Kohézió & $-0,98(4,96)$ & $-2,25(6,479)$ \\
\hline Adaptivitás & $4,816(6,882)$ & $7,812(6,177)$ \\
\hline
\end{tabular}

10

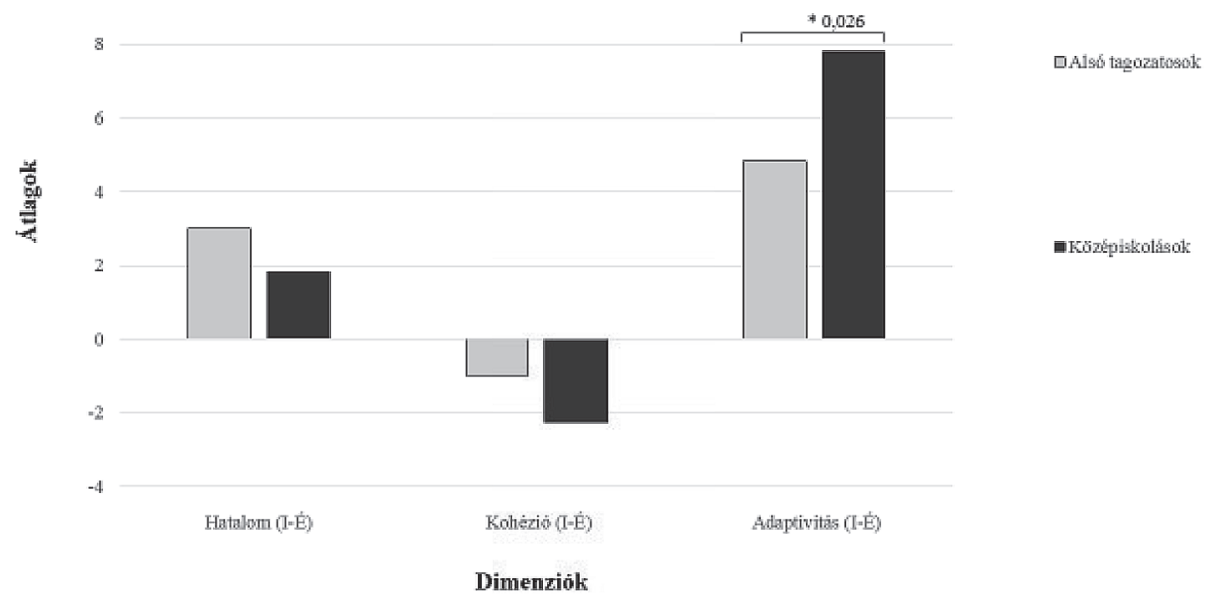

7. ábra: Az észlelt és az ideális családkép relációjában kapott átlagértékek különbségeinek alakulása a két almintán 
Mányai (1990) egyes skálákon kapott pontszámaihoz viszonyítva pedig azt láthatjuk, hogy a kisiskolások és serdülők eredményei is komoly eltéréseket mutatnak a családtipológia teszten korábban mért adatokhoz képest. Így például a családi hatalomra nézve csökkent, az adaptivitásra vonatkozóan azonban megnövekedett változtatási igény fogalmazódott meg a vizsgálati személyekben. Figyelemreméltó, hogy míg Mányai (1990) 10- 14 éves diákjai inkább vágytak a családon belüli kohézió erősödésére, addig jelen kutatás alanyai ellenkező irányú változást szerettek volna elérni mikrokörnyezetükben.

Harmadik hipotézisünk bizonyítására, avagy elvetésére pedig végül azt is megnéztük, hogy a Mányai (1990) által differenciált családtípusok eloszlása hogyan alakul a két tekintett (észlelt- és ideális) családi helyzetre vonatkozóan. Ennek kapcsán azonban fontos megjegyeznünk, hogy a Mányai (1990) által leírt szempontrendszer alapján - különösen az ideális helyzetre vonatkozóan -, az esetek magas arányban nem voltak az egyes családtípusokba $(\mathrm{A} / \mathrm{M} / \mathrm{K})$ besorolhatóak. Míg az alsó tagozatosoknál az észlelt helyzetre nézve a válaszokból 45-öt $(91,837 \%)$, az ideális helyzettel összefüggésben 37-et (75,51\%), addig a középiskolásoknál az észlelt családképnél 46-ot (95,833\%), az ideálisnál pedig 38-at $(79,167 \%)$ tudtunk egyértelmüen típusba sorolni. Mindezek alapján a továbbiakban a Mányai-féle (1990) rendszerbe jól illeszkedő adatokra szükített elemzést mutatjuk be, s a nem egyértelmúen besorolható adatok nyomán elénk kirajzolódó családkép típusokról a megvitatás részben kívánunk részletesebben szólni.

A Khí-négyzet próba az alsó tagozatosoknál az észlelt családképre $\left(\mathrm{x}^{2}=13,733, \mathrm{df}=2\right.$, $\mathrm{p}=0,001)$ vonatkozóan mutatott szignifikáns eltérést. Az egyes családtípusok ideális helyzetre vonatkozó eloszlását tekintve azonban markáns eltérés nem volt kimutatható ennél a korosztálynál $\left(x^{2}=3,297, d f=2, p=0,192\right)$. A középiskolás tesztkitöltők esetében az észlelt- $\left(\mathrm{x}^{2}=9,174, \mathrm{df}=2, \mathrm{p}=0,01\right)$ és ideális családra $\left(\mathrm{x}^{2}=7, \mathrm{df}=2, \mathrm{p}=0,030\right)$ nézve is a három családtípus szignifikáns eltéréssel való előfordulása nyert igazolást. Ezek százalékban kifejezett eredményeit a 8. táblázatban foglaljuk össze (zárójelben az adott családtípusok almintánkénti előfordulási számát is megadva), és a következő, 8. ábrán szemléltetjük.

8. táblázat: A családtipusok százalékos megoszlása és elöfordulása az észlelt- és ideális család esetén, mindkét korosztályra nézve

\begin{tabular}{|l|l|l|l|l|}
\hline \multirow{2}{*}{} & \multicolumn{2}{|l|}{ Észlelt családkép } & \multicolumn{2}{l|}{ Ideális családkép } \\
\cline { 2 - 5 } & Alsó tagozatosok & Középiskolások & Alsó tagozatosok & Középiskolások \\
\hline „K” családtípus & $57,778(26)$ & $54,348(25)$ & $32,432(12)$ & $42,105(16)$ \\
\hline „M” családtípus & $13,333(6)$ & $21,739(10)$ & $45,946(17)$ & $44,737(17)$ \\
\hline „A” családtípus & $28,889(13)$ & $23,913(11)$ & $21,622(8)$ & $13,158(5)$ \\
\hline
\end{tabular}

Eszerint az észlelt családra vonatkozóan mindkét korosztály tagjainál a „K” családtípus fordult elő a legnagyobb arányban, miként az ideális családnál az „,M” típus volt preferált. Az „A” családtípus megjelenése csökkent a vizsgálati személyek által optimálisként megítélt helyzetre vonatkozóan.

Mányai (1990) egyes skálákon nyert értékeinél csupán 15\%-ra volt tehető az alacsonyés magas szintekre rendezhető adatok megjelenése, így az általa mért populációban a „K” családtípus dominálhatott. Ez pedig az észlelt családra vonatkozóan általunk kapott eredményekkel összhangban áll. Az ideális helyzetre nézve azonban az általunk tekintett gyermekek nem csupán eltérö mértékü, de akár ellenkező irányú változtatási igényt is juttattak kifejeztek. Ezáltal napjainkra a gyermekek eltérő ideális családképe mutatkozott, amiről a következő fejezetben részletesebben is szólni fogunk. 


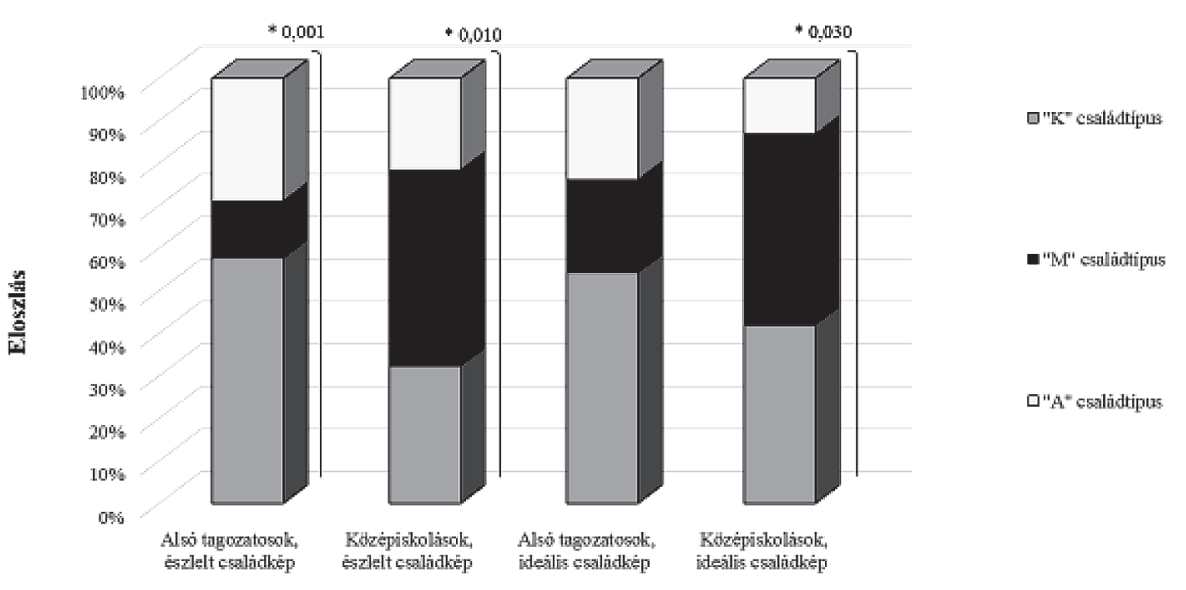

Helyzetek

8. ábra: A családtípusok eloszlásának alakulása az almintákon az észleltés az idealizált családképpel összefüggésben

\section{Megvitatás}

Kutatásunk célkitüzése az volt, hogy feltárjuk, miként észlelik és milyennek szeretnék látni a kisiskolások és a serdülőkorú fiatalok családjukat, mint szocializációjuk alapkövét. Két-két iskolai osztály bevonásával és Mányai (1990) családtipológiai kérdőívét alkalmazva folytattuk le vizsgálatunkat, a tekintett korosztályoknál az eszköz által differenciálható családtípusok almintánkénti eloszlására vonatkozó elemzéseket is elvégezve.

Első hipotézisünk, miszerint az alsós gyermekek mind az észlelt-, mind az ideális családkép esetén kedvezőbbnek ítélik meg családjukat, mint a serdülők, nem nyert igazolást. Az észlelt családkép esetében ugyanis csupán a kohézió tekintetében mutatkozott szignifikáns eltérés az alminták között, az viszont a középiskolások javára történt. Tehát az idősebb korosztály érzelmileg összetartóbb családról adott számot. A serdülök által némileg hierarchikusabbnak ítélt családrendszer képe pedig az észlelt adaptivitással is összefüggésben állhat. Hiszen a válaszokban a vizsgálati személyeket körülvevő elsődleges szocializáció közeg sajátosságain túl a kutatásba vont fiatalok életkori sajátosságai is manifesztálódnak. Vagyis - miként azt a szakirodalmi háttérnél láttuk - a pubertás személyek hajlamosabbak kritikusabban szemlélni a körülvevő világ dolgait (Cole és Cole, 2006; Vajda, 2006; Novák, 2009). Ráadásul a mindinkább önállóságuk kivívására törekvő fiatalok számára különösen érzékeny pont lehet a családon belüli hierarchiában elfoglalt hely, avagy a családtagokkal megélt kapcsolat. Fontos, hogy a serdülökorú fiatalt nevelö családok a felnövekvő gyermek életkorához (és egyedi sajátosságaihoz) igazodva alakítsák a családon belüli kapcsolatokat, s a fiatal szülővel fennálló alá-fölérendeltségi viszonya idővel egyenrangú partneri kapcsolattá váljon. Azonban a formálódó személyiség önállósági törekvései közepette sem nélkülözheti szülei odafigyelését, támogatását. A felelösségvállalásra képes, egészséges felnőtté válás folyamatában tehát paralel jelen kell, hogy legyenek a szülöpáros gyermeki autonómiának teret engedő megnyilvánulásai és a család biztató, meleg klímája (Youniss és Smollar, 1985; Komlósi, 1995b; Barnes, 2004; Cole és Cole 2006; Novák, 2007). 
Az ideális helyzetre nézve minden dimenzióban csak tendenciaszerü eltérések mutatkoztak. Mégis úgy tünik, hogy a középiskolások itt is fontosabbnak ítélték a családon belüli érzelmi kapcsolatokat, miként ezúttal a rendszer rugalmasságának is nagyobb jelentőséget tulajdonítottak. Ehhez képest az alsó tagozatosok számára a szülők - hierarchia értékekben kifejeződő - irányítási stílusa (dominancia, kontroll/vezető szerep, fegyelmezés és döntéshozatal) inkább nyert prioritást. Míg a serdülőkre vonatkozó eredmények magyarázatát az észlelt családdal összefüggésben leírt autonómia törekvések és családi támogatásra való igény együttes serdülőkori megjelenésében (Youniss és Smollar, 1985; Noller és Callan, 1986; Kötters, Krüger és Brake, 1996; Kasten, 2004; Cole és Cole, 2006), úgy az alsó tagozatosok esetében a családi szerepek, értékek elfogadása és viszonyítási pontként történő felfogásában látjuk. A szocializáció során, gyermekkorban elsajátított tudás, gyakorlati ismeretek, készségek pedig megőrződnek és az iméntiekkel közösen a jövendő családi mintákra is hatással lesznek.

Második hipotézisünk, amelynek értelmében a serdülőknél nagyobb eltérések fognak mutatkozni az észlelt és az idealizált családkép között, mint a kisiskolás gyermekeknél, igazolást nyert. A serdülöknél ugyanis - a jelenleg észlelt családi organizáció és ide-

Fontos, hogy a serdülókorú fiatalt neveló családok a felnövekvó gyermek életkorához (és egyedi sajátosságaihoz) igazodva alakitsák a családon belüli kapcsolatokat, s a fiatal szülóvel fennálló alá-fölérendeltségi viszonya idövel egyenrangú partneri kapcsolattá váljon. Azonban a formálódó személyiség önállósági törekvései közepette sem nélkiülözheti szülei odafigyelését, támogatását. ális kép viszonylatában - nagyobb igény fogalmazódott meg a változtatásra. Az adaptivitásnál pedig ezen adat nem is meglepö, hiszen a korosztály szempontjából ez egy sarkalatos pont. Mivel a fiatal önállósodási törekvései mindinkább teret nyernek, a „kis felnőtt" egyre nagyobb beleszólást szeretne a családi ügyekbe, ami a rendszer tagjainak részéről fokozott adaptivitást igényel (Novák, 2009), noha a gyermekkorban megtapasztalt és elfogadott keretek és szabályok betartása ekkor is jogosan elvárt dolog a szülők részéről.

Noha a két vizsgálati helyzetnél (észlelt és ideális) mindössze az alsó tagozatosok kohézióra vonatkozó észlelt családképét tekintve nem mutatkozott szignifikáns különbség az almintáknál- hiszen annak iránya mindkét korcsoportban egyezett, s tagjaik hierarchikusabb és adaptívabb családot idealizáltak - mégis elsősorban az ezen dimenzió kapcsán feltárt változtatási igény minőségére és mennyiségére kell odafigyeljünk. Hiszen annak mértéke egyfelől duplája Mányai (1990) ezen skálán nyert eredményeinek, másfelől pedig azzal ellentétes irányú. Ennek magyarázata pedig túlmutatni látszik az életkori sajátosságokon.

De akkor milyen interpretációval is szolgálhatunk az olvasónak? Alwin (1988) már évtizedekkel korábban felhívta a figyelmet arra a tényre, hogy a családok gyermekkel szembeni elvárásai változnak. Ahogyan korábban az intézményi és felnőtt hatalom iránti engedelmesség, az idők során mindinkább a gyermeki autonómiához kapcsolódó értékek váltak hangsúlyossá. Ez pedig a családon belüli kapcsolati viszonyok és a családok 20 . század során végbemenő szociális, gazdasági és demográfiai változásaira adott válaszaként tekinthető. Ezt támasztja alá az a tény is, hogy a kérdöív szerzője is korábban az ideális családra nézve minden faktorban megnövekedett értékeket igazolt, míg jelen kutatás alkalmával, szük harminc évvel az említett vizsgálatot követően, egészen más kép tárul elénk a fiatalok családról alkotott mentális reprezentációival összefüggésben. 
Végső soron pedig elgondolkodtató, hogy vajon milyen mintázatokat tettek magukévá és visznek tovább ezek a gyermekek, fiatalok, akik mind az észlelt, mind az ideális családképükre nézve ilyen alacsony szintü családon belüli érzelmi kapcsolatokat tapasztalhatnak meg, sőt tekintenek optimálisnak.

Harmadik hipotézisünk, mely szerint a kisiskolásoknál a jelen és az ideális helyzet kiegyensúlyozottabb, a gyermekek szemszögéből nézve jobban funkcionáló családtípusok határozhatóak meg, nem nyert igazolást. Az észlelt családra vonatkozóan ugyanis mindkét korosztály tagjainál a „K” családtípus fordult elő a legnagyobb arányban, miként az ideális családnál az „M” típus volt preferált. Ez azt jelenti, hogy az alsó tagozatosok és a középiskolások egyaránt a leginkább jól funkcionáló, vagyis az egyes dimenziókat tekintve kiegyensúlyozott, közepes szinten működő családtípusba sorolták valós családjukat. S bár - miként Mányai (1990) megjegyzi „az átlagosság nem minden tekintetbe pozitívum, de a beilleszkedés szempontjából nem tekinthető hátránynak" (Mányai, 1990. 124. o.). Hiszen ezen „K” típusú családok a leginkább kiegyensúlyozottak, határaik jól felismerhetőek, alapvetően demokratikus felépítés jellemzi őket. Az individuumok önállósága jó kapcsolati viszonyok közepette nyer teret, ahogyan a feladatok, szerepek struktúrájának optimális elrendezése is ennél a családtípusnál áll fenn a leginkább. Az ideális helyzetre a vágyott családkép „M” típus felé való elmozdulása pedig már inkább fest elénk egy olyan családot, amely mindenbe beleszólást enged tagjai számára, a vezető szerepe nem olyan nyilvánvaló, miként irányítási stílusa is kevésbé határozott. Emellett fokozott hajlam mutatkozik benne az összefonódásra és változékonysággal, csökkent stabilitással rendelkezik a szerep- és feladatmegosztás terén (Mányai, 1990). Az optimálisként megítélt helyzetre vonatkozóan csökkent „A” családtípus megjelenése pedig az autokratikus hatalmi viszonyok, szétesésre hajlamos, rigid és gyenge adaptivitással rendelkező családkép (Mányai, 1990) elutasításáról vall. Ez pedig a serdülőknél az életkori sajátosságokkal, a kisiskolásoknál pedig ugyanezen tendencia immár kisiskoláskorban történő megjelenésével áll összhangban (Novák, 2009).

Mindazonáltal a kutatásunk ezen részében kapott eredményeinek helyes interpretálhatóságának nyilvánvaló korlátja, hogy Mányai (1990) három meghatározott családi alaptípusába számos esetet nem lehetett egyértelmüen besorolni. Erről a jelenségről a kérdőív szerzője is már említést tesz, azonban az esetek és a minta alacsonyabb számára való tekintettel finomabb elemzésre nem vállalkozhatott. Jelen mintán az észlelt családkép az alsósoknál az esetek 8,163 százaléka, a középiskolásoknál pedig 4,167 százaléka, az ideális családképre vonatkozóan a fiatalabb korosztálynál az esetek 24,45 százaléka, az idősebb korosztálynál pedig 20,833 százaléka - talán itt is a feltételezett szocializációs jellegzetességek eltéréseinek okán - nem volt a Mányai-féle (1990) rendszerben értelmezhető. Noha jelen kutatásban ezen „,negyedik típus”, ahol tehát a magas és alacsony skálaértékek együttes megjelenése állt fenn - különösen az ideális helyzetre nézve - nagyobb arányt képviselt, az alacsonyabb résztvevői elemszám okán messzemenő következtetésekbe nem bocsátkoznánk. Ugyanakkor kétségtelen, hogy a nem besorolható eseteknél az érintett vizsgálati személyek a kohézió dimenzióban mind az észlelt, mind az ideális családképnél alacsony pontértékkel bírtak, amihez legalább egy másik dimenzió magas szintje társult. Emellett az ideális családra nézve azt találtuk, hogy az adaptivitás dimenzióban - egy 9. osztályos fiút kivéve - mindenki magas szintet idealizált. Tehát míg vizsgálati személyeink a család alkalmazkodó-képességének tekintetében igen magas szintet tartanának kívánatosnak, addig ezzel párhuzamosan a kohézió alacsony szintjét tartanák megfelelőnek. Vagyis az eredmények szélsőséges, sőt ellentmondásos gondolatokat tükröznek az iskolások családról alkotott képét illetően.

Végezetül még két gondolat: (1) „Mivel a szülők adják meg a családi élet alaphangulatát, és egymáshoz való viszonyuk meghatározza az otthon érzelmi légkörét, döntően fontos, hogy megtudjunk valamit egymás iránti érzéseik jellegéről” (Glueck és Glueck, 
1977. 100. o.). Tudjuk, hogy a családi organizáció, funkcionalitás bázisát képezi a házastársak kapcsolatának minősége. Noha Mányai (1990) kérdőívében nem differenciáltan jelennek meg az egyes alrendszerekre vonatkozó állítások-válaszok, mégis feltételeznünk kell, hogy például a kohézió tekintetében kapott eredmények a szülők között fennálló kapcsolati nehézségek leképeződései is lehetnek. Hiszen a válások száma is magas a hazai populációban, ami az iméntiekben jegyzett problémák, konfliktuskezelési nehézségek következményeként is állhat. Amennyiben pedig ezen feltételezés helytálló, úgy felettébb sajnálatos, hogy az további kedvezőtlen küzdési és viselkedési minták továbbvitelét indukálhatja ezen fiatalok felnövekedése, párkapcsolati elképzelései és családalapítása során. A jövőre vonatkozóan idealizált családkép kohéziós skáláján kapott negatív irányba vágyott elmozdulás legalább is - ebből a perspektívából - nem hat optimálisnak. (2) Mányai (1990) a szélsőségek mentén leírható családtípusokkal összefüggésben a rendszerben élő gyermekek/fiatalok megnövekedett veszélyeztetettségére hívja fel a figyelmet. Noha a szerző maga elsősorban kriminálpszichológiai szempontból közelíti meg a családi működéseket, az általa tekintett és magunk által ismeretes, tudományosan igazolt bizonyítékok fényében kétségtelenül egyéb kockázatokat is látunk a(z) - alapvetően idealizált családkép és „negyedik családtípus” kapcsán felmerült - diszfunkcionális családszerveződésben.

De milyen konklúziót vonhatunk le tehát jelen kutatás eredményeinek áttekintése és eredményeink nyomán? „A felnőttkori szocializáció gyökeres átalakulást hozhat a családdal kapcsolatos értékelésben, érzelmi viszonyulásban, szerepmodellek követésében, egyedi viselkedési formák alkalmazásában" (S. Molnár, 2000. 5. bekezdés). Emellett azonban „a család jelentősége a családi szerepek átadásában a társadalom fejlődésével, átalakulásával együtt maga is változhat” (S. Molnár, 2000. 5. bekezdés). Miként a gyermekek oktatása-nevelés során nem nélkülözhetjük mikrokörnyezetüknek, az őket körülvevő családi háló jelentőségének és lehetséges hatásainak ismeretét, úgy azzal is tisztában kell lennünk, hogy a társadalmi szinten végbemenő folyamatok egyaránt befolyásolják munkánk kereteit és sikerét. A pedagógusnak ezért folyamatosan fejlesztenie kell önmagát, hogy a változó igényeknek megfelelhessen és tudása, kompetenciái révén a gondjaira bízott diákokban felismerje azok gyengéit és erősségeit és hozzájuk a megfelelő kulcsot alkalmazva képes legyen belölük a legjobbat kihozni. Ezen direkt mód és a tanár által közvetetten átadott jó minták pedig hasonlóképpen kedvező irányba segíthetik/terelhetik a gyermek általános fejlödését, melyek azután az egyes diákok életében jelenlévő kockázati tényezők ellenében, avagy mellett hathatnak, illetve kompenzáló jellegük révén védőfaktorként mutatkozhatnak. Hiszen nem csupán a gyermek és szülő kapcsolata kétirányú viszony (Glueck és Gluck, 1977), de a tanuló és nevelöje között is bipoláris kapcsolat áll fenn (Kelemen, 1988). Ezen híd révén pedig az elég jó pedagógus utat találhat a gyermek felé, miként kreativitása és bölcsessége által a család felnőtt tagjait is elérheti, formálhatja, és végső soron növelheti a gondjaira bízott fiatal boldogulási esélyeit a mindennapokban.

\section{Irodalom}

Alwin, D. F. (1988): From Obedience to Autonomy Changes in Traits Desired in Children. Public Opinion. 52. 1. sz. 1924-1978. DOI: 10.1086/269081

Bagdy Emőke (1994): Családi szocializáció és személyiségzavarok. Nemzeti Tankönyvkiadó, Budapest
Bagdy Emőke (2002): A KRV hazai adaptációja. In: Bagdy Emőke (szerk.): Párkapcsolatok dinamikája. Animula, Budapest. 126-169.

Bagdy Emőke, Kóta Hedvig, Safir Erika (2002): Közös Rorschach Vizsgálat: Felvétel, jelölés, interaktometriai elemzés. In: Bagdy E. (szerk.): Párkapcsolatok dinamikája. Animula, Budapest. 99-119. 
Bagdy Emőke és Mirnics Zsuzsanna (2006): Profeszszionális felkészülés a pár és család megismerésére. In: Bagdy Emőke, Baktay Gizella, Mirnics Zsuzsanna (szerk.): Pár-és családi kapcsolatok vizsgálata. Bölcsész Konzorcium, Budapest. 2014. november 7-i megtekintés, http://www.webcreator.hu/tankonyv/

Barnes, G. G. (2004): Család, terápia és gondozás. Családterápiás olvasókönyv sorozat 2. Animula Kiadó, Budapest

Barnes, H. L. és Olson, D. H. (1985): Adolescent Communication and the Circumplex model. Child Development, 56. 438-447.

Bende Zsófia, Radnai Tímea, Habis Melinda és Mirnics Zsuzsanna (2007): Anya-gyermek interakciók két korcsoportnál a Közös Rorschach Vizsgálatban. In: Bagdy Emőke, Mirnics Zsuzsanna és Vargha András (szerk.): Egyén-pár-család. Tanulmányok a pszichodiagnosztikai tesztadaptációs és tesztfejlesztö kutatások köréböl. Animula Kiadó, Budapest. 75-87.

Cole, M. és Cole, S. R. (2006): Fejlödéslélektan. Osiris Tankönyvkiadó, Budapest

Cromwell, R. E. és Peterson, G. W. (1983): Multisystem-Multimethod Family Assessment in Clinical Contexts. Family Process. 22. 147-163. DOI: 10.1111/j.1545-5300.1983.00147.x

Dombi Alice (2013): Pedagógiai professzió, szociálpedagógai kompetenciák. In: Dombi Alice és Dombi Mária (szerk.): Fejezetek a szociálpedagógia köréböl. Universitas Szeged Kiadó, Szeged. 65-78.

Erikson, E. H. (1991): A fiatal Luther és más írások. Gondolat Kiadó, Budapest

Feldman, S. és Gehring, T. M. (1988): Changing Perceptions of Family Cohesion and Power across Adolescence. Child Development. 59. 4. szám. 1034 1045. DOI: $10.2307 / 1130269$

Gehring, T. M. (2010): Family System Test (FAST) kézikönyv. OS Hungary Tesztfejlesztő, Budapest

Gehring, T. M., Marti, D. és Sidler, A. (1994): Family system test (FAST): Are parents' and children's family constructs either different or similar, or both? Child Psychiatry and Human Development, 25. 2. sz. 125-138. DOI: 10.1007/bf02253291

Gerber, G. L. és Kaswan, J. (1971): Expression of emotion through family grouping schemata, distance and interpersonal focus. Journal of Consulting and Clinical Psychology. 36. 370-377. DOI: 10.1037/ h0031108

Glueck, S. és Glueck, E. (1977): A család, az iskola és az utca. In: Münnich Iván és Szakács Ferenc (szerk.): Bünözö fiatalok. A bünözés megelözésének kérdései/ Válogatás kriminálpszichológiai tanulmányokból. Közgazdasági és Jogi Könyvkiadó, Budapest. 96-138.

Goldenberg, H. és Goldenberg, I. (2008): Áttekintés a családról. 2. kötet. Családterápiás sorozat 20. Animula Kiadó, Budapest
Kármán Judit (2004): Családgondozás - krízisprevenció. Medicina Könyvkiadó Rt., Budapest

Kasten, H. (2004): Hogyan válnak felnötté a gyerekek? A serdülö- és az ifjúkor. Akkord Kiadó, Budapest.

Kékes Szabó Marietta (2013): A család, mint pszichoszociális háttér szerepe a fiatalok egészségfejlődésére. Iskolakultúra, 10. 22-36. 2014. október 21-i megtekintés, Iskolakultúra, [on-line] http://www.iskolakultura.hu/i kultura-folyoirat/documents/2013/2013 10.pdf

Kelemen László (1988): Pedagógiai pszichológia. Tankönyvkiadó Vállalat, Budapest

Komlósi Piroska (1995a): A csalási életre nevelés feladatai és nehézségei az egyes életkorokban. In: Komlósi Sándor (szerk.): Családi életre nevelés. Nemzeti Tankönyvkiadó, Budapest. 97-162.

Komlósi Piroska (2000): Családterápiák. In: G. Szőnyi és J. Füredi (szerk.). A pszichoterápia tankönyve. Medicina Könyvkiadó Rt., Budapest. 348-362.

Komlósi Sándor (1995b): Alapvető ismeretek a családról. In: Komlósi Sándor (szerk.): Családi életre nevelés. Nemzeti Tankönyvkiadó, Budapest. 15-92.

Kozma Tamás (2001): Bevezetés a nevelésszociológiába. Nemzeti Tankönyvkiadó Rt., Budapest

Kötters, C., Krüger, H. H. és Brake, A. (1996): Wege aus der Kindheit. Verselbständigungsschritte ins Jugendalter. In: Büchner, P., Fuhs, B. és Krüger, H-H. (szerk.): Vom Teddybär zum ersten Kuß. Wege aus der Kindheit in Ost- und Westdeutschland, S.. Leske und Budrich, Opladen. 99-127. DOI: 10.1007/978-3322-95789-4_5

Kurimay Tamás (2000): A család rendszerelméleti megközelitése. A családi értékrend néhány aspektusa a Magyar Katolikus Püspöki Kar Boldogabb családokért körlevele kapcsán. 2014. május 9-i megtekintés, Magyar Pax Romana, http://www.magyarpaxromana. hu/kiadvanyok/csalad/kurimay.htm

Kurimay Tamás (2004, szerk.): Családterápia és családkonzultáció. Európai távoktatási tankönyv. Coincidencia Kiadó, Budapest

Loveland, N. T., Wynne, L. C. és Singer, M. T. (1963): The Family Rorschach: A New Method for Studying Family Interaction. Family Process, 2. 2. sz. 187-215. DOI: 10.1111/j.1545-5300.1963.00187.x

Mányai Judit (1990): A családi működés diszfunkcióinak szerepe a 11-14 éves korúak veszélyeztetettségének kialakulásában. In: Münnich Iván és Szakács Ferenc (szerk.): Bünözö fiatalok. A bünözés megelözésének kérdései/Válogatás kriminálpszichológiai tanulmányokból/Kézirat. Tankönyvkiadó, Budapest. 109-138.

Noller, P. és Callan, V. J. (1986): Adolescent and parent perceptions of family cohesion and adaptability. Journal of Adolescence, 9. 97-108. 2014. október 30-i megtekintés, Science Direct [on-line] http:// 
Www.sciencedirect.com/science/article/pii/ S0140197186800306 DOI: 10.1016/s01401971(86)80030-6

Novák Éva (2009): A családról mindenkinek. JATEpress, Szeged

Olson, D. H. (1986): Circumplex model VII: Validation studies and FACES III. Family Process. 25. 337-351. DOI: 10.1111/j.1545-5300.1986.00337.x

Olson, D. H. és Gorall, D. M. (2003): Circumplex model of marital and family systems. In: Walsh, F. (szerk.): Normal Family Processes (3rd Ed). Guilford Press, New York, NY. 514-547. DOI: 10.4324/9780203428436

S. Molnár Katalin (2000): A család kialakulása, a családformák történelmi változásai. In: Bekény István, Dányi Dezső, Kollega Tarsoly István (szerk.): Magyarország a XX. században. II. kötet. Természeti környezet, népesség és társadalom, egyházak és felekezetek, gazdaság. Babits Kiadó, Szekszárd. 187203. 2016. augusztus 8-i megtekintés, Magyar Elektronikus Könyvtár, http://mek.oszk.hu/02100/02185/ html/192.html

Szányel Erzsébet (2007): Fejlödéspszichológia Jegyzet - Föiskolás hallgatók számára. Comenius Kft., Pécs

Tóth László (2004): Pszichológiai vizsgálati módszerek a tanulók megismeréséhez. Pedellus Kiadó, Debrecen
Túry Ferenc (2010): A milánói (,szisztémás”) iskola alapja. 2014. május 12-i megtekintés, Semmelweis Egyetem, http://semmelweis.hu/klinikai-pszichologia/files/2012/06/try-milniiskola.pdf

Vajda Zsuzsanna (2006): A gyermek pszichológiai fejlödése. Helikon Kiadó, Budapest

Vargha András, Baktay Gizella, Tóth Melinda, Kisgyörgyné Pongrácz Dóra és Bagdy Emőke (2006) A Circumplex Modellel és az Olson-teszttel kapcsolatos nemzetközi és hazai empirikus vizsgálatok. In: Bagdy Emőke, Baktay Zelka és Mirnics Zsuzsanna (szerk.): Pár- és családi kapcsolatok vizsgálata. Bölcsész Konzorcium, Budapest. 2016. július 28-i megtekintés, http://www.webcreator.hu/tankonyv/hetedik1.html

Vargha András és Tóth Melinda (2007): Az Olsonféle családteszt magyar adaptációja. In: Bagdy Emőke, Mirnics Zsuzsanna és Vargha András (szerk.): Egyén-pár-család. Tanulmányok a pszichodiagnosztikai tesztadaptációs és tesztfejlesztö kutatások köréből. Animula Kiadó, Budapest. 288-309.

Veczkó József (2007): Gyermekvédelem pszichológiai és pedagógiai nézőpontból. Nemzeti Tankönyvkiadó, Budapest

Youniss, J. és Smollar, S. (1985): Adolescent relations with mothers, fathers and friends. University of Chicago Press, Chicago 